\title{
Observations on sea-ice and surface-water geochemistry - implications for importance of sea ice in geochemical cycles in the northern Baltic Sea
}

\author{
M. A. Granskog, ${ }^{1}$ J. Virkanen ${ }^{2}$ \\ ${ }^{1}$ Graduate School for Snow and Ice Research, Department of Geophysics, P.O. Box 4 (Fabianinkatu 24A), \\ University of Helsinki, FIN-00014 Helsinki, Finland \\ ${ }^{2}$ Laboratory of Physical Geography, P.O. Box 9 (Siltavuorenpenger 20A), University of Helsinki, FIN-00014 Helsinki, Finland
}

\begin{abstract}
Sea-ice and surface-water samples collected in January-April 1999 in coastal areas in the northern Baltic Sea were analyzed for particle, nutrient and traceelement concentrations and salinity. Stratigraphic analyses of ice cores were also carried out. Bulk nutrient and trace-element concentrations in sea ice fluctuated widely. Nutrient concentrations in sea ice normalized to sea-water salinities showed that sea ice had, almost without exception, an excess of nutrients compared to underlying waters. For phosphorus and phosphate this can be explained by particle incorporation and snow-ice formation, whereas for nitrogen and the sum of nitrite and nitrate snow-ice formation and other mechanisms are important. The levels of $\mathrm{Al}, \mathrm{Cu}, \mathrm{Fe}$ and $\mathrm{Ni}$ in the ice were similar to those observed in underlying waters. $\mathrm{Pb}$ was observed in detectable concentrations in the ice only. This indicates that sea ice contributes lead to underlying waters during melting, and in some degree also affects the other elements. Furthermore, the observations indicate that incorporation of lead into the ice cover is governed by different processes than for the other elements studied.
\end{abstract}

\section{INTRODUCTION}

Only a few studies have been conducted on the geochemistry of sea ice. These have mainly focused on brine chemistry and/or nutrients (e.g. Clarke and Ackley, 1984; Meese, 1989), while studies devoted to trace elements are rare (e.g. Hoelemann and others, 1999; Granskog, 2000). The importance of sea ice in redistribution of pollutants has been examined (e.g. Pfirman and others, 1995; Lange and Pfirman, 1998). Ackley (1996) discussed the possible role of sea ice as a source of trace elements in the seasonally ice-covered Sea of Okhotsk. Melnikov (1991) suggested that sea-ice and snow decay could cause an increase in the concentrations of lead and other toxic substances in under-ice water layers in Arctic waters. Campbell and Yeats (1982) concluded that sea ice with notably high particle content contributed $\mathrm{Cd}, \mathrm{Cu}$ and Fe to surface waters during melting in Baffin Bay. Recent observations from the Arctic basin indicate that sediment-laden sea ice contributes $\mathrm{Al}$ and Fe to surface waters (Measures, 1999).

Most sea-ice studies have focused on the Arctic and Antarctic regions; there are very few data for the seasonally icecovered Baltic Sea. Leppäranta and others (1998) and Granskog (2000) studied the composition of particulate matter in sea ice. Observations of the nutrient status of Baltic sea ice have been reported more frequently (e.g. Norrman and Andersson, 1994; Mock and others, 1997). To date, however, the results in the Baltic have been obtained from only a limited number of samples and locations. Furthermore, traceelement studies in the Baltic Sea have been undertaken mainly during ice-free periods in pelagic waters (e.g.
Kremling and Petersen, 1984; Brügmann, 1986, 1988). Hence we lack results from wintertime observations and observations from the coastal zone, where a considerable load of these elements are introduced to the Baltic Sea through river discharge. One can expect that the landfast sea-ice cover modifies the spreading of riverine waters, mainly due to reduced mixing during winter. Subsequently, nutrients and trace elements, and other substances in the river runoff, are transported further off the coast in winter than in summer (e.g. Alasaarela and Myllymaa, 1978).

The ice cover also accumulates atmospheric deposition. Nitrogen has been observed to be enriched in the topmost layers of the ice cover in the Baltic Sea due to atmospheric loading (Rahm and others, 1995). Considering the levels of Al, Cu, Fe and $\mathrm{Pb}$ in snow along the Finnish coast, reported by Soveri and Peltonen (1996), one would also expect snow deposition to increase the levels of these elements in the ice cover. The potential importance of atmospheric deposition is revealed by the fact that precipitation accounts for about $35 \%$ of the gross fresh-water input to the Baltic Sea (HELCOM, 1991).

In this paper we present particulate-matter, traceelement and nutrient concentrations in sea ice and surface waters along the northern Baltic Sea coast. The objective of this work is to determine how salinity, particulate matter and ice structure is related to trace-element and nutrient concentrations in the ice. Furthermore, the observations give an indication of the concentrations of nutrients and trace elements in the ice-covered transition zone, and an implication of the role sea ice plays in wintertime dispersal of riverine waters. 


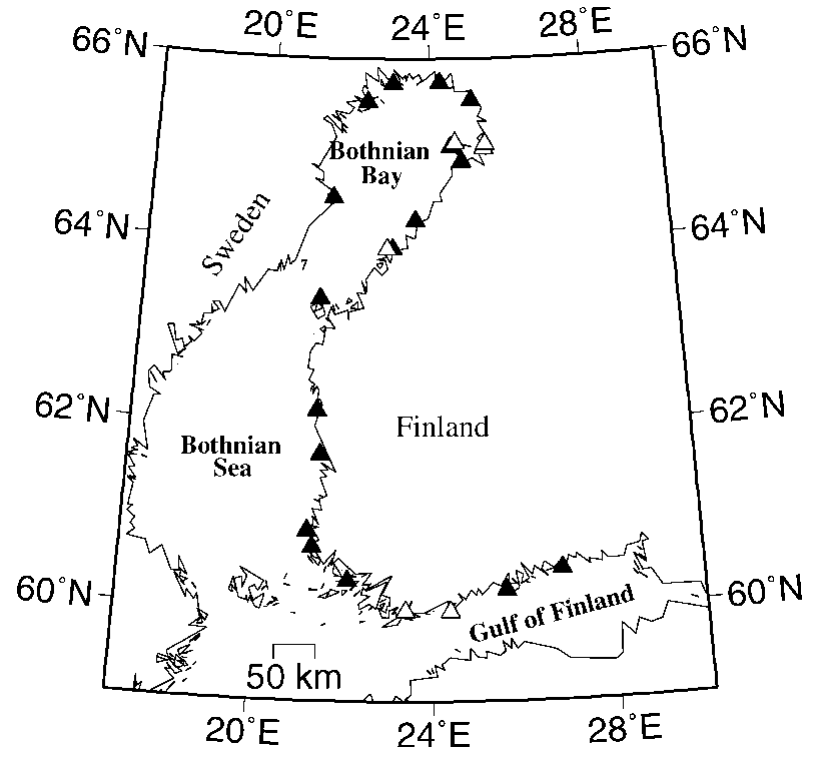

Fig. 1. Map of the northern Baltic Sea and location of sampling sites. Sites with both ice and water samples are denoted with $\boldsymbol{\Delta}$, whereas $\triangle$ indicates sites where only ice samples were collected.

\section{MATERIALS AND METHODS}

\section{Sample collection}

Sea-ice and surface-water samples were collected during January, March and April 1999 along the Finnish coast of the Gulf of Finland and the Gulf of Bothnia and the Swedish coast of the Bay of Bothnia (Fig. 1). Altogether 23 ice cores and 17 surface-water samples were collected from coastal sites with level landfast ice. The water depth at the sites was 5-20 m.

A $13 \mathrm{~cm}$ diameter coring auger was used to collect ice cores. In the field some of the thicker cores were divided into two or three segments (in total 34 segments), with a stainless-steel saw, based on visual inspection of the ice core into opaque and clear parts. The segments were immediately put into plastic tubing and placed in a freezer, at approximately $-15^{\circ}$ to $-20^{\circ} \mathrm{C}$, within 1 hour from retrieval and kept frozen until chemical analysis.

Surface-water samples were collected through the core hole with a Limnos water sampler (Limnos Ltd), at about $1 \mathrm{~m}$ depth beneath the ice/water interface and put into $0.5 \mathrm{~L}$ acid-washed polyethylene bottles which were frozen until chemical analysis. For total particulate matter (TPM) analysis, $2 \mathrm{~L}$ samples were collected and then frozen until determination.

\section{Analytical methods}

Sediment content (TPM), salinity and nutrients (phosphorus, $\mathrm{P}_{\text {tot }}-\mathrm{P}$; nitrogen, $\mathrm{N}_{\text {tot }}-\mathrm{N}$; phosphate, $\mathrm{PO}_{4}-\mathrm{P}$; sum of nitrite and nitrate, $\mathrm{NO}_{2+3}-\mathrm{N}$ ) were determined in all samples. Total $\mathrm{Al}$, $\mathrm{Cd}, \mathrm{Cu}, \mathrm{Fe}, \mathrm{Ni}$ and $\mathrm{Pb}$ and dissolved $\mathrm{Cu}$ and $\mathrm{Fe}$ concentrations were determined from 20 selected ice-core segments and all water samples.

Prior to chemical analysis all samples were thawed at room temperature. Ice samples were carefully moved into acid-washed buckets before melting. Care was taken to remove all surfaces from the ice cores which had potentially been contaminated during sampling. The samples were shaken during the melting process to make sure that the sample temperature did not increase much above the melting point prior to the next step in the pre-treatment process.

TPM was determined as the material retained by a glassfiber filter (Whatman $\mathrm{GF} / \mathrm{F}$, nominal pore size $0.7 \mu \mathrm{m}$ ). About $1000 \mathrm{~mL}$ of sample was filtered through pre-weighed filters. Several blanks were used (filtered with Nanopure water). Before weighing, filters were dried at $105^{\circ} \mathrm{C}$ and cooled in a desiccator. Weights for total mass were corrected by the average weight change of the blanks.

The fractions of $\mathrm{P}$ and $\mathrm{N}$ were analyzed according to Grasshoff (1983) and Koroleff (1983). Phosphate was measured from a filtered sample, and $\mathrm{P}_{\text {tot }}-\mathrm{P}$ from an unfiltered sample, after pressure digestion with peroxodisulfate $\left(120^{\circ} \mathrm{C}, 30 \mathrm{~min}\right) . \mathrm{NO}_{2+3}$ was determined using automated cadmium reduction method with an autoanalyzer. Total $\mathrm{N}$ was pressure-digested with peroxodisulfate $\left(120^{\circ} \mathrm{C}, 30 \mathrm{~min}\right)$. The accuracy and precision of the methods have been controlled by use of certified reference materials and in intercalibration exercises.

The trace elements were analyzed according to national standards (SFS, 1990a, b). The dissolved metals were separated by filtering through a $0.45 \mu \mathrm{m}$ membrane. Unfiltered samples were digested with $\mathrm{HNO}_{3}\left(67 \%\right.$ p.a.) under pressure $\left(120^{\circ} \mathrm{C}\right.$, $30 \mathrm{~min}$ ) for total trace-metal analysis (acid-leachable) (SFS, 1980). The determination of trace metals was performed with flameless AA (Varian GTA 96). The concentration of metals in particulate matter was estimated by the difference between soluble and total metal concentrations. The accuracy and precision of the methods used have been controlled by participation in intercalibration exercises and by use of certified reference materials (VKI). An experiment is underway to detect any contamination during the sampling process itself.

The structural properties of the ice cores were studied by observing the optical behaviour of thin sections between crossed polarizers. The ice was divided into granular and columnar ice, the former being snow and/or frazil ice.

Table 1. Summary of data on sea-ice core and surface-water properties and nutrients

\begin{tabular}{|c|c|c|c|c|c|c|c|c|}
\hline Sample type & Number of samples & Ice thickness & Salinity & $\begin{array}{l}\text { TPM } \\
\mathrm{psu}\end{array}$ & $\begin{array}{l}\mathcal{N}_{\text {tot }}-\mathcal{N} \\
\mathrm{mg} \mathrm{L}^{-1}\end{array}$ & $\begin{array}{c}\mathcal{N O}_{2+3}-\mathcal{N} \\
\mu \mathrm{M}\end{array}$ & $\begin{array}{c}P_{\mathrm{tot}}-P \\
\mu \mathrm{M}\end{array}$ & $\begin{array}{c}\mathrm{PO}_{4}-\mathrm{P} \\
\mu \mathrm{M}\end{array}$ \\
\hline $\begin{array}{l}\text { Sea-ice } \\
\text { segments }\end{array}$ & 34 & $\begin{array}{c}45 \\
(19-86)\end{array}$ & $\begin{array}{c}0.2 \\
(0.0-0.7)\end{array}$ & $\begin{array}{c}4.4 \\
(1.1-90)\end{array}$ & $\begin{array}{c}20.8 \\
(1.1-54.3)\end{array}$ & $\begin{array}{c}2.5 \\
(0.2-7.1)\end{array}$ & $\begin{array}{c}0.5 \\
(0.1-1.9)\end{array}$ & $\begin{array}{c}0.2 \\
(0.0-0.7)\end{array}$ \\
\hline $\begin{array}{l}\text { Surface } \\
\text { water }\end{array}$ & 17 & $\mathrm{~N} / \mathrm{A}$ & $\begin{array}{c}2.0 \\
(0.0-4.5)\end{array}$ & $\begin{array}{c}1.9 \\
(0.2-6.8)\end{array}$ & $\begin{array}{c}24.1 \\
(10.7-67.8)\end{array}$ & $\begin{array}{c}9.3 \\
(0.4-29.3)\end{array}$ & $\begin{array}{c}0.5 \\
(0.0-1.2)\end{array}$ & $\begin{array}{c}0.3 \\
(0.0-0.7)\end{array}$ \\
\hline
\end{tabular}




\section{RESULTS AND DISCUSSION}

In general, the ice samples had a similar physical structure, with a granular-ice layer on the top and columnar ice in the bottom. However, the total thickness varied from 19 to $86 \mathrm{~cm}$ (Table 1), and the thermodynamic history of the cores might differ considerably, especially since surface melting had started at the southernmost sites at the time of sampling. The relative thickness of the granular-ice fraction decreased northwards; granular ice accounted for up to $30 \%$ of the total ice thickness in the Gulf of Finland, but only about $10 \%$ in the northernmost samples. In the Bay of Bothnia the ice was covered with a $10-30 \mathrm{~cm}$ thick snow layer, whereas in the southern sites there was a snow slush layer on the ice surface.

Strong variabilities in space (and time) must be taken into account when studying the geochemistry of surface waters (and sea ice) in the large study area. Both natural and anthropogenic processes act upon the locations sampled in different spatial and time-scales. The atmospheric input generally tends to decrease northwards (e.g. $\mathrm{N}, \mathrm{Fe}, \mathrm{Cd}, \mathrm{Ni}, \mathrm{Pb}$ ), and the riverine load is higher than atmospheric input into the Gulf of Finland (e.g. Cd, Cu, $\mathrm{Zn}, \mathrm{Pb}$ ) (HELCOM, 1991, 1993). In the Gulf of Bothnia the atmospheric load is generally higher than the riverine load, despite the high river discharge (HELCOM, 1991, 1993). Locally, sources such as industry and municipalities also determine the geochemical properties of surface waters. The main aim of this paper, despite the facts mentioned above which make the coastal waters rather heterogeneous in character, is to relate the geochemical properties of the sea ice to (1) its physical properties and (2) those of the underlying waters, not to study the spatial variability in the geochemistry of sea ice and surface waters in detail.

\section{TPM}

The results from TPM analyses show that sea ice contained, on average, twice as much particulate matter as the underlying water. On average there was $4.4 \mathrm{mg} \mathrm{L}^{-1}(1.1-90)$ in ice and $2.0 \mathrm{mg} \mathrm{L}^{-1}(0.2-6.8)$ in underlying water (Table 1). This can be expected, since after a (land-fast) ice cover has formed, mixing is reduced, causing suspended particles in the underlying water column to settle. Based on structural analyses of the ice cores, the highest values of TPM were associated with granular ice (not including snow ice), and the maximum value $\left(90 \mathrm{mg} \mathrm{L}^{-1}\right)$, observed in ice west of Hailuoto island in the Bay of Bothnia, was caused by entrainment of sand-sized particles from the sea floor from approximately $8 \mathrm{~m}$ depth. Sediment-laden sea ice has been observed previously in the same region (Granskog, 2000).

\section{Nutrients}

Our results for nutrient analysis of sea ice and surface waters (Table 1) are in good agreement with previously published nutrient data from the Baltic (e.g. Kangas and others, 1993; Mock and others, 1997).

Correlation coefficients between TPM, salinity and nutri-

\footnotetext{
${ }^{*}$ Note that both correlations were calculated without inclusion of the two samples with very high TPM (33.6 and $90 \mathrm{mg} \mathrm{L}^{-1}$ ).
}
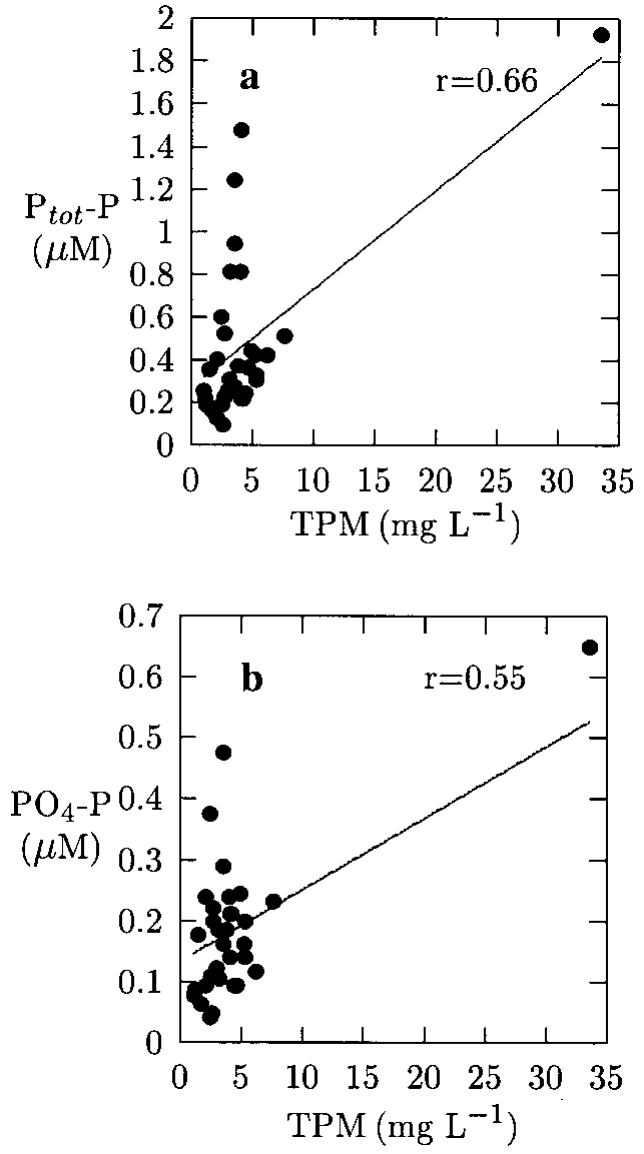

Fig. 2. $P_{\text {tot }}-P$ vs TPM ( $\left.a\right)$ and $P_{4}-P$ vs TPM $(b)$ in the ice samples. Best-fit linear regression line included (solid line). Regression equations were calculated without inclusion of the samples with TPM of $33.6 \mathrm{mg} \mathrm{L}^{-1}$, and $90 \mathrm{mg} \mathrm{L}^{-1}$ (higher value also omitted from the figure).

ents in the ice samples were computed. The most significant correlations in the ice were found between TPM and $\mathrm{P}_{\text {tot }}-\mathrm{P}$ $(r=0.66)$, TPM and $\mathrm{PO}_{4}-\mathrm{P}(r=0.55)$ (see Fig. $2{ }^{*}$ and $\mathrm{P}_{\text {tot }}-\mathrm{P}$ and $\mathrm{PO}_{4}-\mathrm{P}(r=0.67)$, whereas $\mathrm{N}_{\text {tot }}-\mathrm{N}$ and $\mathrm{NO}_{2+3}-\mathrm{N}$ showed no significant correlations ( $r=0.07$ and $r=0.05$, respectively) with TPM. This indicates that particle incorporation into the ice cover could explain some of the phosphorus and phosphate found in the ice, whereas nitrogen and nitrite+ nitrate seem to be governed by other processes. From Figure 2a it can be seen that the $\mathrm{P}_{\text {tot }}-\mathrm{P}$ values are divided into two subgroups by the regression curve. The subgroup associated with higher $\mathrm{P}_{\text {tot }}-\mathrm{P}$ values, some of them also having high $\mathrm{PO}_{4}-\mathrm{P}$ values, have TPM values below the average and are from the topmost segment of nine samples, which mainly consisted of granular ice, possibly snow ice. Hence, snow-ice formation seems to affect phosphorus, and to some extent phosphate, concentrations in the ice. However, the highest values of phosphorus and phosphate (1.9 and $0.7 \mu \mathrm{mol} \mathrm{L}^{-1}$, respectively) were observed in young $19 \mathrm{~cm}$ thick ice with a notably high particle content $\left(33 \mathrm{mg} \mathrm{L}^{-1}\right)$, due to entrainment of silt-sized material into a $2 \mathrm{~cm}$ thick frazil-ice layer during a freeze-up storm.

$\mathrm{N}_{\text {tot }}-\mathrm{N}$ and $\mathrm{NO}_{2+3}-\mathrm{N}$ also show higher values in the topmost segments of those cores divided into two or three sections. This could be a result of snow-ice formation as observed by Rahm and others (1995) in the Bay of Bothnia. However, the values for nitrogen are considerably lower than those reported by Rahm and others (1995). Their results were based on only a few ice samples, and the nutrients were deter- 
Table 2: Summary of data on total trace metals $\left(\mu g L^{-1}\right)$ in sea ice and surface waters

\begin{tabular}{|c|c|c|c|c|}
\hline Trace metal & Sea ice & Surface water & $\operatorname{Ref.} I^{\mathbf{a}}$ & $\operatorname{Ref.} 2^{\mathbf{b}}$ \\
\hline Aluminium & $\begin{array}{c}201.3 \\
(35.5-430)\end{array}$ & $\begin{array}{c}201.9 \\
(24.5-527)\end{array}$ & & \\
\hline Cadmium & $\begin{array}{c}0.2 \\
\text { (d.1. }-0.95)\end{array}$ & $\begin{array}{c}0.1 \\
(\text { d.l. }-0.45)\end{array}$ & 0.28 & 0.31 \\
\hline Copper & $\begin{array}{c}6.0 \\
(2.2-11.4)\end{array}$ & $\begin{array}{c}8.5 \\
(2.9-24.5)\end{array}$ & 1.11 & $(7.29-8.24)$ \\
\hline Iron & $\begin{array}{c}270.2 \\
(73.9-661.2)\end{array}$ & $\begin{array}{c}285.9 \\
(58.9-897.0)\end{array}$ & 2.02 & $(25.28-59.90)$ \\
\hline Lead & $\begin{array}{c}9.1 \\
\text { (d.l.-70.7) }\end{array}$ & d.l. & 0.35 & \\
\hline Nickel & $\begin{array}{c}2.7 \\
\text { (d.1.-8.8) }\end{array}$ & $\begin{array}{c}2.7 \\
\text { (d.1.-4.9) }\end{array}$ & 0.24 & 0.37 \\
\hline
\end{tabular}

Notes: Values are mean values, with the range in parentheses. Data are presented for 17 surface-water samples and 20 selected sea-ice-core segments. d.l. denotes that in some samples the concentrations were below the detection limit.

${ }^{\mathrm{a}}$ Melnikov (1991); sea ice in the Russian Arctic, avg. 1986-89 $\left(\mu \mathrm{g} \mathrm{kg}^{-1}\right)$.

${ }^{\mathrm{b}}$ Campbell and Yeats (1982); sea ice in Baffin Bay (one sample).

mined with higher vertical resolution (elevated values of nitrogen, nitrate and nitrite in the topmost $5 \mathrm{~cm}$ ). The values presented in this paper, however, are bulk values and do not exclude the possibility of higher values in the pure snow-ice fraction. Also Norrman and Andersson (1994) observed high nutrient concentrations in sea ice in the Gulf of Bothnia, and associated the high values with atmospheric precipitation. A comparison with the results presented by Mock and others (1997) from the western Baltic indicates that the longer ice season in the northern parts of the Baltic makes snow-ice formation, i.e. atmospheric deposition, more important for the nutrient status of sea ice than in the southern parts.

Comparing nutrient concentrations in the ice with those in the surface waters diluted to the salinity of the ice samples (i.e. normalized to the under-ice water salinity), the following conclusions can be drawn: $\mathrm{P}_{\text {tot }}-\mathrm{P}, \mathrm{PO}_{4}-\mathrm{P}, \mathrm{N}_{\text {tot }}-\mathrm{N}$ and $\mathrm{NO}_{2+3}-\mathrm{N}$ values in the ice were generally enriched relative to surface waters. However, in the northernmost samples $\mathrm{NO}_{2+3}-\mathrm{N}$ was depleted when the surface-water salinities were low $(<0.3 \mathrm{psu}$ (practical salinity units)) and the sample consisted of columnar ice with extremely low salinities $(<0.1 \mathrm{psu})$. The enrichment of $\mathrm{NO}_{2+3}-\mathrm{N}$, and subsequently of $\mathrm{N}_{\text {tot }}-\mathrm{N}$, is possibly a result of bacterial activity in the ice or atmospheric deposition onto the ice, as discussed above. Phosphorus and phosphate, to some extent, are also governed by particle inclusions. Even though we do not know the nutrient concentrations in the surface waters during ice growth, we can assume that the maximum concentrations occurred at the time when the samples were collected, according to observations by Kangas and others (1993).

Furthermore the nutrients showed poor correlations with salinity, indicating that nutrients were independent of salinity effects, as observed by Meese (1989) in Arctic waters. This suggests that secondary processes, such as biological activity, atmospheric deposition and particle entrapment, govern the nutrient status of Baltic Sea ice in the coastal regions.

\section{Trace elements}

The high trace-element concentrations in this study, shown in Table 2, reflect the location of the samples in a transition zone between the fresh-water inputs and the more saline pelagic waters. For $\mathrm{Al}, \mathrm{Cu}, \mathrm{Fe}$ and $\mathrm{Ni}$ the observations in surface waters agree reasonably well with those in stream waters draining to the study area (Lahermo and others, 1996). The dissolved levels of $\mathrm{Cu}\left(1.6-6.5\right.$ and $0.7-2.6 \mu \mathrm{g} \mathrm{L}^{-1}$ in the waters and the ice, respectively) and $\mathrm{Fe}$ (17.6-123.6 and 8.5-100.4 $\mu \mathrm{g} \mathrm{L}^{-1}$ in the waters and the ice, respectively) are generally between the values reported by Kremling and Petersen (1984) and Lahermo and others (1996). The levels of $\mathrm{Cu}, \mathrm{Fe}$ and $\mathrm{Ni}$ observed by Campbell and Yeats (1982) in Baffin Bay were in the lower range of our observations. The levels in the ice are considerably higher than those reported by Melnikov (1991) for sea ice in the Russian Arctic (Table 2). An exception is cadmium. Detectable $\mathrm{Cd}$ concentrations $\left(>0.1 \mu \mathrm{g} \mathrm{L}^{-1}\right)$ were observed in only a few of our water and ice samples. However, the observed Cd values are considerably higher than reported elsewhere (e.g. Louskari and others, 1991) and must therefore be viewed with caution.

The mean (total) levels of $\mathrm{Al}, \mathrm{Cu}, \mathrm{Fe}$ and $\mathrm{Ni}$ in the ice were close to the observations in the surface waters (Table 2). $\mathrm{Pb}$ was observed in detectable concentrations $\left(>1 \mu \mathrm{g} \mathrm{L}^{-1}\right)$ in the ice only. This indicates that sources other than the sea water where the ice is formed have to exist for lead. This could reflect atmospheric deposition of $\mathrm{Pb}$ onto the icecovered sea surface, as indicated by observations of the surface microlayer in the Baltic by Brügmann and others (1992). Also Melnikov (1991) observed that sea ice in the Russian Arctic contributes lead to underlying waters during decay, and suggested atmospheric deposition as a reason.

This cannot be confirmed from our observations, although the levels of $\mathrm{Pb}$ in snow have been observed to be relatively high, up to $14 \mu \mathrm{g} \mathrm{L}^{-1}$, at coastal sites in the Gulf of Finland (Soveri and Peltonen, 1996). The relatively high element levels indicate that sea ice is a potential source of $\mathrm{Pb}$ to surface waters, and less important for $\mathrm{Al}, \mathrm{Cu}, \mathrm{Fe}$ and $\mathrm{Ni}$, during sea-ice decay.

Frequently for $\mathrm{Fe}$ and $\mathrm{Cu}$ the particulate fraction represents concentrations that are several times higher than for their dissolved counterparts. On average, $82 \%$ and $66 \%$ of $\mathrm{Fe}$ and $\mathrm{Cu}$, respectively, was in the particulate fraction in the ice. In surface waters the values decreased to $73 \%$ and $48 \%$. Values for Fe are similar to, whereas values for $\mathrm{Cu}$ are much higher than, those reported by Brügmann and others (1992) for pelagic waters in the Baltic. The decrease in the relative contribution of the dissolved fraction of the metals in the ice can be attributed to brine rejection during ice formation. Because sea ice excludes salts and other dissolved substances during growth, the ice has probably lower dissolved concentrations than the water it grew from. However, the conditions at the sampling sites are not constant during the ice season, with respect to salinity and trace elements. This makes quantitative estimates of the importance of brine expulsion impossible from the bulk concentrations measured. Temporal observations throughout the ice season would be necessary to be able to quantitatively determine the importance of brine exclusion for dissolved trace-metal concentrations in sea ice. In the northernmost parts of the Baltic, there is a tendency for decreased Fe and Al levels in the uppermost segments. This is probably caused by snow-ice formation because snow has considerably lower $\mathrm{Fe}$ and $\mathrm{Al}$ concentrations than the coastal waters in the Bay of Bothnia: about 50 and $500 \mu \mathrm{g} \mathrm{L}^{-1} \mathrm{Fe}$ in snow and surface waters, respectively (Soveri and Peltonen, 1996).

Extremely high Fe values $\left(600-900 \mu \mathrm{g} \mathrm{L}^{-1}\right)$ were observed in under-ice waters in the northernmost Bay of Bothnia. 
Concentrations in the ice were also high in this region, 200$600 \mu \mathrm{g} \mathrm{L}^{-1} \mathrm{Fe}$. The particulate fraction composed $>85 \%$ of Fe in these ice samples. The high values of several elements (e.g. $\mathrm{Fe}$ and $\mathrm{Al}$ ) in the Bay of Bothnia, in comparison to other parts of the Baltic, have been attributed to the high river discharge into this basin (e.g. Kremling and Petersen, 1984). The high levels of $\mathrm{Fe}$ (and $\mathrm{Al}$ ) in the under-ice waters indicate dispersal of riverine waters beneath the ice, as observed, for example, by Alasaarela and Myllymaa (1978).

All trace elements showed poor correlations with salinity and TPM in the ice samples analyzed. Several inter-element relationships were indicated by the correlation analysis (e.g. $\mathrm{Fe} / \mathrm{Al}, \mathrm{Fe} / \mathrm{Cu}$ and $\mathrm{Fe} / \mathrm{Ni}$ were closely related to each other). One striking exception was $\mathrm{Pb}$, which showed poor correlation with all the other measured parameters, suggesting different mechanisms for incorporation of lead into the ice cover.

\section{GONGLUSIONS}

From our observations in the coastal regions of the northern

Baltic Sea, the following conclusions can be drawn.

sea ice contains on average twice as much TPM as surface waters. To some degree this difference is caused by the time lag between the start of ice formation and the time of sampling (settling of particles in the water column after initial ice formation).

nutrients are independent of salinity effects. Particle entrapment, atmospheric deposition and snow-ice formation are important for the nutrient status of Baltic Sea ice. The influence of biological activity cannot be judged from our observations.

the levels of $\mathrm{Al}, \mathrm{Cu}, \mathrm{Fe}$ and $\mathrm{Ni}$ in the ice are similar to those in the surface waters, whereas $\mathrm{Pb}$ was observed at detectable levels in sea ice only. Therefore, we argue that incorporation of lead is governed by different processes than for the other elements studied.

the excess of lead in sea ice, compared to the underlying waters, indicates that sea ice contributes lead to surface waters during melting in the coastal areas.

sampling and analytical procedures could be improved in order to more accurately identify the mechanisms affecting the nutrient and trace-element status of sea ice in the Baltic Sea (see below).

The importance of biological processes could not be determined from our observations. In retrospect we can judge that observations of ammonium, nitrate and nitrite separately, silica, chl- $a$ and snow properties (density, nutrients, trace elements, etc.) would have been useful. For future work, the ice samples for chemical analysis should be divided according to the physical structure obtained from thin-section analysis and not in the field. Differentiation of snow and frazil ice would also be useful (e.g. using stable oxygen isotopes), in order to be able to distinguish more accurately the different sources for nutrients and trace elements. Furthermore the temporal variability during the ice season affects the ice properties, so a monitoring throughout the whole ice season would be needed to study the processes affecting sea-ice geochemistry in more detail. Observations in the pelagic waters would also shed new light on the importance of sea ice on biogeochemical processes in other seasonally ice-covered parts of the Baltic Sea.

\section{ACKNOWLEDGEMENTS}

The authors are grateful to A. Blanco Sequeiros and P. Kosloff for providing some ice cores for this study. The comments of two reviewers and S. Pfirman improved the original manuscript considerably. This study has been funded by the Academy of Finland through project "Coastal sea ice and oceanography of the Baltic Sea in winter", and the Graduate School for Snow and Ice Research, University of Helsinki. M.A.G. acknowledges the Finnish Academy of Science and Letters for providing funding to participate in the symposium.

\section{REFERENCES}

Ackley, S. F. 1996. Biogeochemical interactions in the ice-covered Sea of Okhotsk: contrasts and similarities with the Antarctic sea ice zone. In 11th International Workshop on the Okhotsk Sea and Arctic: the Physics and Biogeochemistry implied to Global Cycles, 29 February-1 March 1996, Tokyo. Proceedings. Tokyo, Science and Technology Agency. Japan Marine Science and Technology Center, 111-114.

Alasaarela, E. and U. Myllymaa. 1978. Investigations into the dispersal of river and waste waters in the northeastern part of the Bothnian Bay in 1975-1977. Finn. Mar. Res. 244, 173-182.

Brügmann, L. 1986. Particulate trace metals in waters of the Baltic Sea and parts of the adjacent NE Atlantic. Beitr. Meereskunde 55, 3-18.

Brügmann, L. 1988. Some peculiarities of the trace-metal distribution in Baltic waters and sediments. Mar. Chem., 23, 425-440.

Brügmann, L., P. C. Bernard and R. van Grieken. 1992. Geochemistry of suspended matter from the Baltic Sea. 2. Results of bulk trace metal analysis by AAS. Mar. Chem., 38, 303-323.

Campbell, J. A. and P. A. Yeats. 1982. The distribution of manganese, iron, nickel, copper and cadmium in the waters of Baffin Bay and the Canadian Arctic Archipelago. Oceanol. Acta, 52 (2), 161-168.

Clarke, D. B. and S. F. Ackley. 1984. Sea ice structure and biological activity in the Antarctic marginal ice zone. 7. Geophys. Res., 89(C2), 2087-2095.

Finnish Standards Association (SFS). 1980. Metal content of water, sludge and sediment determined by atomic absorption spectroscopy. Atomization in a graphite furnace. General principles and guidelines. Helsinki, Finnish Standards Association. (Standard 304.)

Finnish Standards Association (SFS). 1990a. Metal content of water, sludge and sediment determined by flameless atomic absorption spectrometry. Atomization in a graphite furnace. General principles and guidelines. Helsinki, Finnish Standards Association. (Standard 5074.)

Finnish Standards Association (SFS). 1990b. Metal content of water, sludge and sediment determined by flameless atomic absorption spectrometry. Atomization in a graphite furnace. Special guidelines for aluminium, cadmium, cobalt, chromium, copper, lead, manganese, nickel and iron. Helsinki, Finnish Standards Association. (Standard 5502.)

Granskog, M. A. 2000. Baltic Sea ice as a medium for storage of particulate matter and elements. ICES 7. Mar. Sci., 56, Supplement, 172-175.

Grasshoff, K. 1983a. Determination of nitrate. In Grasshoff, K., M. Ehrnhardt and K. Kremling, eds. Methods of seawater analysis. Second edition. Weinheim, Verlag Chemie, 143-150.

HELCOM. 1991. Airborne pollution load to the Baltic Sea 1986-1990. Baltic Sea Environ. Proc. 39.

HELCOM. 1993. Second Baltic Sea pollution load compilation. Baltic Sea Environ. Proc. 45.

Hoelemann, J. A., M. Schirmacher, H. Kassens and A. Prange. 1999. Geochemistry of surficial and ice-rafted sediments from the Laptev Sea (Siberia). Estuarine Coastal Shelf Sci., 49(1), 45-59.

Kangas, P., E. Alasaarela, H.-G. Lax, S. Jokela and C. Storgård-Envall. 1993. Seasonal variation of primary production and nutrient concentrations in the coastal waters of the Bothnian Bay and the Quark. Aqua Fennica, 23(2), 165-176.

Koroleff, F. 1983b. Determination of phosphorus. In Grasshoff, K., M. Ehrnhardt and K. Kremling, eds. Methods of seawater analysis. Second edition. Weinheim, Verlag Chemie, 125-139.

Kremling, K. and H. Petersen. 1984. Synoptic survey of dissolved trace metal levels in Baltic surface waters. Mar. Pollution Bull., 15(9), 329-334.

Lahermo, P., J. Väänänen, T. Tarvainen and R. Salminen. 1996. Suomen geokemian atlas. Osa 3: Ympäristögeokemia — purovedet ja sedimentit. Espoo, Geologian Tutkimuskeskus, Geological Survey of Finland.

Lange, M. A. and S. L. Pfirman. 1998. Arctic sea ice contamination: major characteristics and consequences. In Leppäranta, M., ed. Physics of icecovered seas. Vol. 2. Helsinki, University of Helsinki. Department of Geophysics, 651-681. 
Leppäranta, M., M. Tikkanen and P. Shemeikka. 1998. Observations of ice and its sediments on the Baltic Sea coast. Nord. Hydrol., 29(3), 199-220.

Louekari, K., H. Saarikosko and R. Joki-Kokko. 1991. Cadmium in Finnish environment. Helsinki, Water and Environment Research Institute. (Publication A 70.)

Measures, C. I. 1999. The role of entrained sediments in sea ice in the distribution of aluminium and iron in the surface waters of the Arctic Ocean. Mar. Chem., 68(1-2), 59-70.

Meese, D. A. 1989. The chemical and structural properties of sea ice in the southern Beaufort Sea. CRREL Rep. 89-25.

Melnikov, S. A. 1991. Report on heavy metals. In The state of the Arctic environment reports. Vol. 2. Rovaniemi, Arctic Centre, University of Lapland, 82-153.

Mock, T., K. M. Meiers and H. C. Giesenhagen. 1997. Bacteria in sea ice and underlying brackish water at $54^{\circ} 26^{\prime} 50^{\prime \prime}$ (Baltic Sea, Kiel Bight). Mar. Ecol. Prog. Ser., 158, 23-40.

Norrman, B. and A. Andersson. 1994. Development of ice biota in a temperate sea area (Gulf of Bothnia). Polar Biol., 14(8), 531-537.

Pfirman, S. L., H. Eicken, D. Bauch and W. F. Weeks. 1995. The potential transport of pollutants by Arctic sea ice. Sci. Total Environ., 159(2-3), 129-146.

Rahm, L., B. Håkansson, P. Larsson, E. Fogelqvist, G. Bremle and J. Valderrama. 1995. Nutrient and persistent pollutant deposition on the Bothnian Bay ice and snow fields. Water, Air, Soil Pollut., 84(1-2), 187-201.

Soveri, J. and K. Peltonen. 1996. Lumen ainepitoisuudet ja talviaikainen laskeuma Suomessa vuosina 1973-1993. Helsinki, Finnish Environment Institute. (Suomen Ympäristö 6.) 